\title{
Selected biochemical and hematological abnormalities in Nigerians with human immunodeficiency virus and hepatitis $C$ virus coinfection
}

\author{
This article was published in the following Dove Press journal: \\ Hepatic Medicine: Evidence and Research \\ 29 June 2011 \\ Number of times this article has been viewed
}

\section{Olive Obienu \\ Sylvester Nwokediuko}

Gastroenterology Unit, Department of Medicine, University of Nigeria Teaching Hospital Ituku/Ozalla, Enugu, Nigeria
Correspondence: Sylvester Nwokediuko Gastroenterology Unit, Department of Medicine, University of Nigeria Teaching Hospital Ituku/Ozalla, PMB 01 I 29 Enugu, Nigeria Tel +23480332 I8I 8 I

Email sylvester.nwokediuko@unn.edu.ng
Background: Liver disease has emerged as a major cause of morbidity and mortality in patients with human immunodeficiency virus (HIV) and hepatitis $\mathrm{C}$ virus (HCV) coinfection, now that antiretroviral therapy has become more effective and has prolonged life expectancy in HIV-infected patients. The main objectives of this study were to determine the prevalence of $\mathrm{HIV} / \mathrm{HCV}$ coinfection and the pattern of hematological and biochemical abnormalities associated with such dual infection.

Methods: In this study, patients with HIV infection (cases) were tested for anti-HCV antibodies. There was a control group made up of apparently healthy individuals who came to hospital for medical examination for various reasons. They also had an anti-HCV antibody test. Those who tested positive for anti-HCV antibodies among the cases and control subjects were further evaluated for hemoglobin concentration, total white cell count, platelet count, and liver function.

Results: One hundred and eighty HIV-infected patients and 180 control subjects participated in the study. The seroprevalence of anti-HCV antibodies in the HIV-infected patients and control subjects were $6.7 \%$ and $4.4 \%$, respectively $(P=0.57)$. Serum total bilirubin, conjugated bilirubin, and alkaline phosphatase were significantly higher in the HIV/HCV coinfected patients compared with their HCV monoinfected counterparts $(P=0.0396,0.0001$, and 0.0016 , respectively). The mean hemoglobin, white cell count, platelet count, and CD4+ T lymphocyte count were significantly lower in the HIV/HCV coinfected patients than the HCV monoinfected control group ( $P=0.0082,0.0133,0.0031$, and 0.0001 , respectively).

Conclusion: The seroprevalence of anti-HCV antibodies in HIV-infected Nigerian patients is $6.7 \%$. Patients with HIV/HCV coinfection have lower blood counts, higher serum bilirubin, and higher serum alkaline phosphatase compared with patients having HCV monoinfection.

Keywords: human immunodeficiency virus, hepatitis $\mathrm{C}$ virus, coinfection, biochemical, hematological abnormalities

\section{Introduction}

Human immunodeficiency virus (HIV) and hepatitis C virus (HCV) are global health problems. Due to shared routes of transmission, coinfection with the two viruses is common and represents an emerging area of interest both in clinical practice and research. ${ }^{1}$

In the US, $15 \%-30 \%$ of HIV-infected individuals are coinfected with $\mathrm{HCV}^{2,3}$ However, the proportion of HIV-infected patients with HCV varies substantially according to the HIV risk factor. Among patients who acquired HIV from blood product transfusion or intravenous drug use, even higher rates $(60 \%-90 \%)$ of $\mathrm{HCV}$ 
coinfection have been reported, whereas risk factors such as sexual transmission have lower rates. ${ }^{4}$

The mortality related to HIV has dropped considerably over the past $10-15$ years with the introduction of highly active antiretroviral therapy. ${ }^{5}$ Following the introduction of highly active antiretroviral therapy, there has been a sharp increase in the number of deaths due to end-stage liver disease among the HIV-HCV coinfected population. ${ }^{6,7}$ This has led to increased research into the evaluation and management of coinfected patients.

Sexual transmission is the predominant source of the spread of the HIV/AIDS epidemic in sub-Saharan Africa. ${ }^{8}$ Consequently, the $\mathrm{HIV} / \mathrm{HCV}$ coinfection rate is expected to be lower than that in developed countries. In Gambia it was reported as $0.6 \% .{ }^{9}$ In Nigeria, prevalence rates ranging from $4.5 \%$ to $10.3 \%$ have been reported in various studies. ${ }^{10-13}$ However, there are no published studies regarding HIV/HCV coinfection in south east Nigeria.

Management of each of these viral infections requires a rigorous process of proper clinical evaluation and laboratory testing which are mandatory, not only at the initiation of treatment, but have to be repeated several times in the course of follow-up. The process becomes even more complex when there is coinfection. Both viruses affect the liver individually, ${ }^{14-17}$ and collectively. ${ }^{18-21}$ It follows that the clinician needs to have a good idea of certain parameters of liver function in $\mathrm{HIV} / \mathrm{HCV}$ coinfected patients before, during, and after treatment. Therefore, this study was designed to determine the prevalence of $\mathrm{HCV}$ infection in HIV-infected patients and to evaluate selected biochemical and hematological indices.

\section{Methods and materials}

This was a cross-sectional study of consecutive treatmentnaïve HIV-infected patients seen at the University of Nigeria Teaching Hospital Enugu between May 2007 and April 2009. The study was approved by the University of Nigeria Teaching Hospital research ethics committee and informed consent was obtained from each participant before inclusion. There was a control arm made up of age-matched and gender-matched HIV-negative persons who came for preemployment medical examination, a premarriage medical examination, or voluntary blood testing.

Venous blood $(5 \mathrm{~mL})$ was obtained from the cases and control subjects. Anti-HCV antibody was assayed in the two groups using a third-generation enzyme linked immunosorbent assay which utilizes recombinant $\mathrm{HCV}$ antigen manufactured by DRG International, Marburg, Germany.
This test has a sensitivity of $95 \%$, a specificity of $97.5 \%$, and a coefficient of variation $\leq 15 \%$. Biochemical tests were also carried out on the sera of the HIV-infected patients (cases) and control subjects using the Bayer ${ }^{\circledR}$ Plus clinical chemistry analyzer. Hematological tests for the determination of hemoglobin, white cell count, and platelet count were carried out on the cases and control subjects using an automated hematology analyzer (Sysmex XT 2000i; Sysmex Corporation, Kobe, Japan). CD4+ T lymphocyte count was determined in HIV-infected patients using the CyFlow ${ }^{\circledR}$ Counter (Partec, Swedesboro, NJ).

\section{Statistical analysis}

The data were analyzed using SPSS version 15.0 (SSPS Inc, Chicago, IL). Continuous variables were summarized as means \pm standard deviation, while categorical variables were presented as percentages. Differences between proportions were determined using the Chi-squared test, and $P$ values $\leq 0.05$ were considered statistically significant.

\section{Results}

There were $180 \mathrm{HIV}$-infected patients ( 80 males [44.4\%] and 100 females [55.6\%]). There were also 180 control subjects (91 males [50.6\%] and 89 females [49.4]). The mean age of the HIV-infected patients was $36.4 \pm 8.4$ years while the mean age of the control subjects was $37.0 \pm 7.9$ years. Twelve HIVinfected patients $(6.7 \%)$ and eight control subjects (4.4\%) were anti-HCV positive. The difference between the proportions was not statistically significant $(P=0.57)$. Table 1 illustrates the anti-HCV serology status of the HIV-infected patients and control subjects.

Selected hematological indices in the cases and controls are depicted in Table 2. Mean hemoglobin concentration, mean leukocyte count, mean platelet count, and mean CD4+ T lymphocyte count were significantly lower in the HIV/HCV coinfected patients compared with the HCV monoinfected individuals $(P=0.0082,0.0133,0.0031$, and 0.0001 , respectively). Conversely, serum total and conjugated bilirubin were significantly higher in the $\mathrm{HIV} / \mathrm{HCV}$ coinfected group compared with the HCV monoinfected group $(P=0.0396$ and 0.0001 , respectively). Serum alkaline phosphatase was

Table I Anti-HCV in HIV-infected patients and control subjects

\begin{tabular}{lll}
\hline Group & $\begin{array}{l}\text { Anti-HCV } \\
\text { positive }\end{array}$ & Percentage \\
\hline HIV-infected patients $(\mathrm{n}=180)$ & 12 & 6.7 \\
Control subjects $(\mathrm{n}=180)$ & 8 & 4.4 \\
Total $(\mathrm{n}=360)$ & 20 & 5.6 \\
\hline
\end{tabular}

Abbreviations: $\mathrm{HCV}$, hepatitis $\mathrm{C}$ virus; HIV, human immunodeficiency virus. 
Table 2 Selected hematological abnormalities in HIV/HCV coinfection and HCV monoinfection

\begin{tabular}{lcccc}
\hline Parameter & HIV/HCV coinfection & HCV monoinfection & $\boldsymbol{t}$ value & $\boldsymbol{P}$ value \\
\hline Mean hemoglobin concentration $(\mathrm{g} / \mathrm{dL})$ & $9.66 \pm 1.80$ & $12.47 \pm 1.4$ & 3.16 & $0.0082^{*}$ \\
Total WBC $\left(\times 10^{9}\right.$ cells $\left./ \mu \mathrm{L}\right)$ & $4.04 \pm 1.27$ & $5.96 \pm 0.89$ & 2.95 & $0.0133^{*}$ \\
Platelet count $\left(\times 10^{9}\right.$ cells $\left./ \mu \mathrm{L}\right)$ & $175.1 \pm 80.85$ & $333.6 \pm 59.66$ & 3.76 & $0.003 I^{*}$ \\
CD4+ T lymphocyte count $(\mathrm{cell} / \mathrm{sL})$ & $220.5 \pm 53.73$ & $505.8 \pm 90.4$ & $5.8 \mathrm{I}$ & $0.000 \mathrm{I}^{*}$ \\
\hline
\end{tabular}

Note: *Statistically significant.

Abbreviations: $\mathrm{HCV}$, hepatitis $\mathrm{C}$ virus; HIV, human immunodeficiency virus; WBC, white cell count.

significantly higher in the $\mathrm{HIV} / \mathrm{HCV}$ coinfected patients compared with their HCV monoinfected counterparts $(P=0.0016)$. Table 3 shows selected biochemical abnormalities in the cases and controls.

\section{Discussion}

In this study, the seroprevalence of anti-HCV antibodies in the HIV-infected patients was $6.7 \%$ while in the control group it was $4.4 \%$. The difference was not statistically significant. There is a possibility that some of the HIV-infected patients may have tested falsely negative for anti-HCV because of profound immunosuppression, as shown by the significantly lower mean CD4+ T lymphocyte count. This pattern has been reported by other investigators. ${ }^{22,23}$ In such situations, an HCV RNA assay would be the appropriate method for evaluating $\mathrm{HCV}$ infection. Unfortunately, that was not done in this study because of funding and technical constraints. Further studies including viral load estimation will shed more light on this.

Serum total and conjugated bilirubin were significantly higher in the HIV/HCV coinfected patients compared with the HCV monoinfected patients $(P=0.0396$ and 0.0003 , respectively). Cholestasis is a recognized histological feature of HIV/HCV coinfection. ${ }^{24}$ Whether the observed higher conjugated bilirubin level in the HIV/HCV coinfected group is related to this histological finding cannot be inferred because liver biopsy was not part of the study.

Furthermore, there is a special form of hepatitis known as fibrosing cholestatic hepatitis which has a strong associa- tion with immunosuppression. It is a rapidly progressive, sometimes fatal, form of liver injury originally reported in liver transplant recipients with recurrent hepatitis. ${ }^{25}$ It has now been recognized frequently in chronic hepatitis B patients and hepatitis $\mathrm{C}$ patients under immunosuppression. ${ }^{26}$ The histologic hallmarks in the liver include marked hepatocytic injury, severe cholestasis, and periportal and pericellular fibrosis. ${ }^{27,28}$ In contrast with the pathogenesis of chronic hepatitis in immunocompetent patients attributed to cellular immune-mediated hepatocytolysis, fibrosing cholestatic hepatitis has been postulated to result from unimpeded viral replication within hepatocytes, culminating in a direct cytopathic effect in the setting of immunosuppression. ${ }^{29}$ High-level expression of viral antigens ( $\mathrm{HbsAg}$ and $\mathrm{HbcAg}$ ) has been visualized directly by immunohistochemical staining in affected livers and measured by quantitative analysis, such as radioimmunoassay of tissue homogenates. ${ }^{30}$ The possibility that higher serum conjugated bilirubin levels in $\mathrm{HIV} / \mathrm{HCV}$ coinfected patients represents an early stage in progression to fibrosing cholestatic hepatitis remains to be confirmed.

HIV infection modifies the natural history of $\mathrm{HCV}$ infection by accelerating the histological progression of $\mathrm{HCV}$ infection, leading to cirrhosis and end-stage liver disease in a shorter period of time. ${ }^{18,31-33}$ Another way to explain the higher level of serum conjugated bilirubin in the $\mathrm{HIV} / \mathrm{HCV}$ coinfected group is to regard it as a manifestation of rapid histological progression to cirrhosis. The clinical importance of this observation is that such biochemical

Table 3 Selected biochemical abnormalities in HIV/HCV coinfection and HCV monoinfection

\begin{tabular}{lcccc}
\hline Parameter & HIV/HCV coinfection & HCV monoinfection & $t$ value & $P$ value \\
\hline Alanine transaminase $(\mathrm{IU} / \mathrm{L})$ & $7.9 \pm 1.29$ & $8.0 \pm 1.96$ & 0.1122 & 0.9127 \\
Aspartate transaminase $(\mathrm{IU} / \mathrm{L})$ & $1 \mathrm{I} .46 \pm 1.73$ & $1 \mathrm{I} .16 \pm 2.23$ & 0.2755 & $0.788 \mathrm{I}$ \\
Total bilirubin $(\mu \mathrm{mol} / \mathrm{L})$ & $23.89 \pm 8.72$ & $14.1 \pm 3.95$ & 2.334 & $0.0396^{*}$ \\
Conjugated bilirubin $(\mu \mathrm{mol} / \mathrm{L})$ & $13.55 \pm 2.27$ & $6.92 \pm 1.43$ & 5.808 & $0.000 I^{*}$ \\
Alkaline phosphatase $(\mathrm{IU} / \mathrm{L})$ & $102.3 \pm 17.37$ & $58.2 \pm 20.46$ & 4.165 & $0.0016^{*}$ \\
Total protein $(\mathrm{g} / \mathrm{L})$ & $68.48 \pm 6.90$ & $69.36 \pm 1.35$ & 0.279 & 0.7854 \\
Albumin $(\mathrm{g} / \mathrm{L})$ & $34.60 \pm 3.096$ & $36.58 \pm 3.527$ & 1.066 & 0.3094 \\
\hline
\end{tabular}

Note: *Statistically significant.

Abbreviations: HCV, hepatitis C virus; HIV, human immunodeficiency virus; WBC, white cell count. 
abnormalities may represent surrogate markers of liver disease progression. Larger prospective studies will be more elucidatory.

Hemoglobin concentration was significantly lower in the HIV/HCV coinfected patients compared with the HCV monoinfected control subjects. This may be due to an additive or synergistic effect of the two infections in the coinfected group. Anemia is a very common finding in patients with HIV infection, particularly in individuals with more advanced HIV disease. ${ }^{34}$ The causes include changes in cytokine production with subsequent effects on hematopoiesis, ${ }^{35-37}$ decreased erythropoietin concentration, ${ }^{38,39}$ opportunistic infectious agents, such as Mycobacterium avium complex ${ }^{40}$ and Parvovirus B19. ${ }^{41}$ Other less common mechanisms include vitamin B12 deficiency ${ }^{42}$ and autoimmune destruction of red blood cells. ${ }^{43}$ Similarly, in untreated HCV monoinfection, different types of immune-mediated cytopenias might be severe and clinically significant. However, hemolytic anemia and severe thrombocytopenia are the most frequently observed cytopenias. ${ }^{44}$ Pure red cell aplasia has also been reported in association with $\mathrm{HCV}$ infection. ${ }^{45}$

The mean platelet count was significantly lower in the HIV/HCV coinfected patients compared with the $\mathrm{HCV}$ monoinfected group. Again, this may be due to an additive or a synergistic effect of the two infections. Thrombocytopenia was first associated with the acquired immune deficiency syndrome before the discovery of HIV. ${ }^{46}$ The mechanisms involved include accelerated platelet clearance due to immune complex disease, ${ }^{47-49}$ antiplatelet glycoprotein antibodies, ${ }^{50,51}$ and/or antiHIV antibodies that crossreact with platelet membrane glycoprotein (antigenic mimicry). ${ }^{52,53}$ Direct infection of megakaryocytes results in defective platelet production and megakaryocytic apoptosis. ${ }^{54,55}$ Similarly, thrombocytopenia is common in chronic $\mathrm{HCV}$ infection and the mechanisms include advanced liver fibrosis and manifest cirrhosis, ${ }^{56}$ lack of hepatic-derived thrombopoietin, ${ }^{57}$ direct cytopathic involvement of platelets and megakaryocytes, ${ }^{58,59}$ and $\mathrm{HCV}$-associated immunoglobulins which induce thrombocytopenia via an immunological mechanism similar to that operating in immune thrombocytopenic purpura. ${ }^{60}$

Leukopenia is inherent in HIV infection. Apart from lymphocyte depletion, which is the critical event, granulocytopenia is a problem commonly encountered with HIV infection. ${ }^{61}$ The pathogenesis is multifactorial, including an autoimmune mechanism $^{62,63}$ and impaired granulopoiesis. ${ }^{64,65}$

In conclusion, the seroprevalence of anti-HCV antibody in HIV-infected Nigerian patients is $6.7 \%$. Coinfected patients are more likely to have deranged hematological and biochemical parameters compared with HCV monoinfected patients. This may be due to an additive or a synergistic effect of the two infections.

\section{Disclosure}

The authors report no conflicts of interest in this work.

\section{References}

1. Thomas DL. HIV/HCV co-infection: comorbidity and clinical implications. Adv Stud Med. 2005;5:S352-S355.

2. Sherman KE, Rouster SD, Chung RT, Rajicic N. Hepatitis C virus prevalence among patients infected with human immunodeficiency virus: a cross-sectional analysis of the US Adult AIDS Clinical Trials Group. Clin Infect Dis. 2002;34:831-837.

3. Tedaldi EM, Hullsiek KH, Malvestatto CD, et al. Prevalence and characteristics of hepatitis $\mathrm{C}$ virus co-infection in a human immunodeficiency virus clinical trials group: the Terry Beirn Community Programs for Clinical Research on AIDS. Clin Infect Dis. 2003;36:1313-1317.

4. Sulkowski MS, Thomas DL. Hepatitis C in the HIV-infected person. Ann Intern Med. 2003;138:197-207.

5. Palella FJ Jr, Delaney KM, Moorman AC, et al. Declining morbidity and mortality among patients with advanced human immunodeficiency virus infection: HIV Outpatient Study Investigators. $N$ Engl $J$ Med. 1998;338:853-860.

6. Darby SC, Ewart DW, Giagrande PL, et al. Mortality from liver cancer and liver disease in haemophiliac men and boys in UK given blood products contaminated with hepatitis C. UK Haemophiliac Centre Directors' Organization. Lancet. 1997;350:1425-1431.

7. Bica I, McGovern B, Dhar R, et al. Increasing mortality due to end-stage liver disease in patients with human immunodeficiency virus infection. Clin Infect Dis. 2001;32:492-497.

8. Schmid GP, Buve A, Mugyeniyi P, et al. Transmission of HIV-1 infection in sub-Saharan Africa and effect of elimination unsafe injections. Lancet. 2004;363:482-488.

9. Mboto CI, Fielder M, Russel A, Jewel AP. The prevalence of HIV 1, HIV 2, hepatitis C and co-infection in The Gambia. West Afr J Med. 2009;28:306-309.

10. Agwale SM, Tanimoto L, Womack C, et al. Prevalence of HCV co-infection in HIV-infected individuals in Nigeria and characterization of HCV genotypes. J Clin Virol. 2004;31 (Suppl 1):S3-S6.

11. Inyama PU, Uneke JC, Anyanwu IG, Njoku MO, Idoko HJ, Idoko AJ. Prevalence of antibodies to hepatitis $\mathrm{C}$ virus among Nigerian patients with HIV infection. Online J Health Allied Scs. 2005;2:2.

12. Muktar HM, Alkali CN, Jones EM. Hepatitis B and C co-infection in HIV/AIDS patients attending ARV centre ABUTH, Zaria, Nigeria. Highland Med Res J. 2006;4:39-45.

13. Olokoba AB, Olokoba LB, Salawu FK, et al. Hepatitis C virus and human immunodeficiency virus co-infection in North-Eastern Nigeria. Res J Med Sci. 2008;2:217-219.

14. Albisetti M, Braegger CP, Stallmach T, Willi UV, Nadal D. Hepatic steatosis: a frequent non-specific finding in HIV-infected children. Eur J Paed. 1999;158:971-974.

15. Poles MA, Dieterich DT, Schwarz ED, et al. Liver biopsy findings in 501 patients with human immunodeficiency virus (HIV). J Acquir Immune Defic Syndr Hum Retrovirol. 1996;11:170-177.

16. Trojan A, Kreuzer KA, Flury R, Schmild M, Schneider J, Schroder S. Liver changes in AIDS. Retrospective analysis of 227 autopsies of HIV-positive patients. Pathologe. 1998;19:194-200. German.

17. [No authors listed]. Recommendations for prevention and control of hepatitis $\mathrm{C}$ virus (HCV) infection and HCV-related chronic liver disease. MMWR Recomm Rep. 1998;47:1-39. 
18. Soto B, Sanchez-Quijano A, Rodrigo L, et al. Human immunodeficiency virus infection modifies the natural history of chronic parenterally acquired hepatitis $\mathrm{C}$ with an unusual rapid progression to cirrhosis. J Hepatol. 1997;26:1-5.

19. Thomas DL, Astemborski J, Rai RM, et al. The natural history of hepatitis $\mathrm{C}$ virus infection: host, viral and environmental factors. JAMA. 2000;284:450-456.

20. De Luca A, Bugarini R, Lepri AC. Co-infection with hepatitis viruses and outcome of initial antiretroviral regimes in previously naïve HIV-infected subjects. Arch Intern Med. 2002;162:2125-2132.

21. Anderson KB, Guest JL, Rimland D. Hepatitis C virus co-infection increases mortality in HIV-infected patients in the highly active antiretroviral therapy era: data from the Atlanta VA Cohort Study. Clin Infect Dis. 2004;39:1507-1513.

22. Ladep NG, Agbaji O, Agaba P, et al. Does immunological status affect the prevalence of hepatitis $\mathrm{C}$ virus infection among HIV/AIDS patients? Niger J Med. 2007;16:231-234.

23. Adewole OO, Anteyi E, Ajuwon Z, et al. Hepatitis B and C virus co-infection in Nigerian patients with HIV infection. J Infect Dev Ctries. 2009;3:369-375.

24. Bierhoff E, Fischer HP, Willsch E, et al. Liver histopathology in patients with concurrent chronic hepatitis C and HIV infection. Virchows Arch. 1997;430:271-277.

25. Davies SE, Portmann BC, O’Grady JG, et al. Hepatic histological findings after transplantation for chronic hepatitis B virus infection, including a unique pattern of fibrosing cholestatic hepatitis. Hepatology. 1991;13:150-157.

26. Zylberberg H, Carnot F, Mamzer MF, et al. Hepatitis C virusrelated fibrosing cholestatic hepatitis after renal transplantation. Transplantation. 1997;63:158-160.

27. Furuta K, Takahashi T, Aso K, Hoshino H, Sato K, Kakita A. Fibrosing cholestatic hepatitis in a liver transplant recipient with hepatitis $\mathrm{C}$ virus infection: a case report. Transplant Proc. 2003;35:389-391.

28. Rosenberg PM, Farrell JJ, Abraczinskas DR, Graeme-Cook FM, Dientag JL, Chung RT. Rapidly progressive fibrosing cholestatic hepatitis-hepatitis C virus in HIV co-infection. Am J Gastroenterol. 2002;97:478-483.

29. Toth CM, Pascual M, Chung RT, et al. Hepatitis C virus-related fibrosing cholestatic hepatitis after renal transplantation: response to interferonalpha therapy. Transplantation. 1998;66:1254-1258.

30. Lau JY, Bain VG, Davies SE, et al. High-level expression of hepatitis B viral antigens in fibrosing cholestatic hepatitis. Gastroenterology. 1992;102:956-962.

31. Jones R, Dunning J, Nelson M. HIV and hepatitis C co-infection. Int J Clin Pract. 2005;59:1082-1092.

32. Leen CLS. Hepatitis C and HIV co-infection. Int J STD AIDS. 2004;15: 289-295.

33. Mohsen AH, Eastbrook PJ, Taylor C, et al. Impact of human immunodeficiency virus (HIV) on the progression of liver fibrosis in hepatitis C virus infected patients. Gut. 2003;52:1035-1040.

34. Zon Li, Groupman JE. Hematologic manifestations of the human immunodeficiency virus (HIV). Semin Hematol. 1988;25:208-218.

35. Zauli G, Re MC, Visani G, et al. Evidence for a human immunodeficiency virus type-1 mediated suppression of uninfected hemapoietic (CD341) cells in AIDS patients. J Infect Dis. 1992;166:710-716.

36. Furlini G, LaPlaca M. Tat protein stimulates production of transforming growth factor-b 1 by bone marrow macrophages: a potential mechanism for human immunodeficiency virus-1 induced hematopoiesis suppression. Blood. 1992;80:3036-3043.

37. Maciejewski JP, Weichold FF, Young NS. HIV-1 suppression in haematopoiesis in vitro mediated by envelope glycoprotein and TNF-alpha. J Immunol. 1994;153:4303-4310.

38. Spirak JL, Barnes DC, Fuchs E, Quinn TC. Serum immunoreactive erythropoietin in HIV-infected patients. JAMA. 1989;261:3104-3107.

39. Camacho J, Poveda F, Zamorano AF, Valencia ME, Vazquez JJ, Arnalich F. Serum erythropoietin levels in patients with advanced human immunodeficiency virus infection. Br J Haematol. 1992;82:608-614.
40. Horsburgh CR. Mycobacterium avium complex infection in the acquired immunodeficiency syndrome. $N$ Engl J Med. 1991;324: 1332-1338.

41. Naides SJ, Howard EJ, Swack NS, True CA, Stapleton JT. Parvovirus B19 infection in human immunodeficiency virus type-1-infected persons failing or intolerant to zidovudine therapy. J Infect Dis. 1993;168:101-105.

42. Remacha AF, Riera A, Cadafalch J, Grimferrer E. Vitamin B-12 abnormalities in HIV-infected patients. Eur J Haematol. 1991;47:60-64.

43. Ciaffoni S, Luzzati R, Roata C, Turrini A, Antonello O, Aprili G. Presence and significance of cold agglutinins in patients with HIV infection. Haematologica. 1992;77:233-236.

44. Ramos-Casals M, Garcia-Carrasco M, Lopez-Medrano F, et al. Severe autoimmune cytopenias in treatment naïve hepatitis $\mathrm{C}$ virus infection: clinical description of 35 cases. Medicine (Baltimore). 2003;82:87-96.

45. Al-Awami Y, Sears DA, Carrum G, Udden MM, Alter BP, Conlon CL. Pure red cell aplasia associated with hepatitis $\mathrm{C}$ infection. Am J Med Sci. 1997;314:113-117.

46. Morris L, Distenfeld A, Amorosi E, Karpatkin S. Autoimmune thrombocytopenic purpura in homosexual men. Ann Intern Med. 1982; 96(6 Pt 1):714-717.

47. Liebman Ha, Stasi R. Secondary immune thronbocytopenicpurpura. Curr Opin Hematol. 2007;14:557-573.

48. Karpatkin S, Nardi M, Lennette ET, Byne B, Poiesz B. Anti-human immunodeficiency virus type 1 antibody complexes on platelets of seropositive thrombocytopenic homosexuals and narcotic addicts. Proc Natl Acad Sci U S A. 1988;85:9763-9767.

49. Karpatkin S, Nardi M. Autoimmune anti-HIV 1 gp120 antibody with anti-idiotype-like activity in sera and immune complexes of HIV 1-related immunologic thrombocytopenia. J Clin Invest. 1992; $89: 356-364$

50. Bettaieb A, Oksenhendler E, Fromont P, Duedari N, Bierling P. Immunochemical analysis of platelet auto-antibodies in HIV-related thrombocytopenic purpura: a study of 68 patients. Br J Haematol. 1989; 73:241-247.

51. Nardi MA, Liu LX, Karpatkin S. GPIIIa-(49-66) is a major pathophysiologically relevant antigenic determinant for anti-platelet GPIIIa of HIV 1-related immunologic thrombocytopenia. Proc Natl Acad Sci U S A. 1997;94:7589-7594.

52. Bettaieb A, Fromont P, Louache F, et al. Presence of cross-reactive antibody between human immunodeficiency virus (HIV) and platelet glycoproteins in HIV-related immune thrombocytopenic purpura. Blood. 1992;80:162-169.

53. LiZ, Nardi M, Karpatkin S. Role of molecular mimicry to HIV-1 peptides in HIV-1-related immunologic thrombocytopenia. Blood. 2005;106:572-576.

54. Ballem PJ, Belzberg A, Devine DV, et al. Kinetic studies of the mechanism of thrombocytopenia in patients with human immunodeficiency virus infection. N Engl J Med. 1992;327:1779-1784.

55. Sakaguchi M, Sato T, Groopman JE. Human immunodeficiency virus infection of megakaryocytic cells. Blood. 1991;77:481-485.

56. Wang CS, Yao WJ, Wang ST, Chang TT, Chou P. Strong association of hepatitis $\mathrm{C}$ virus (HCV) infection and thrombocytopenia: implications from a survey of a community with hyperendemic HCV infection. Clin Infect Dis. 2004;39:790-796.

57. Afdhal N, McHutchison J, Brown R, et al. Thrombocytopenia associated with chronic liver disease. J Hepatol. 2008;48:1000-1007.

58. Bordin G, Ballare M, Zigrossi P, et al. A laboratory and thrombokinetic study of HCV-associated thrombocytopenia: a direct role of $\mathrm{HCV}$ in bone marrow exhaustion? Clin Exp Rheumatol. 1995;Suppl 13:S39-S43.

59. De Almeida AJ, Campos-de-Magalhaes M, Okawa MY, et al. Hepatitis $\mathrm{C}$ virus-associated thrombocytopenia: a controlled prospective virological study. Ann Hematol. 2004;83:434-440.

60. Aref S, Sleem T, El Menshawy N, et al. Anti-platelet antibodies contribute to thrombocytopenia associated with chronic hepatitis $\mathrm{C}$ virus infection. Hematology. 2009;14:277-281. 
61. Zon LI, Groopman JE. Hematologic manifestations of the human immunodeficiency virus (HIV). Semin Hematol. 1988;25:208-218.

62. Murphy MF, MetcalfeP, Waters AH, et al. Incidence and mechanism of neutropenia and thrombocytopenia in patients with human immunodeficiency virus infection. Br J Haematol. 1987;66:337-340.

63. van der Lelie J, Lange JM, Voss JJ, van Dalen SA, von dem Borne AE. Autoimmunity against blood cells in human immunodeficiency virus (HIV) infection. Br J Haematol. 1987;67:109-114.
64. Stella CC, Ganser A, Hoelzer D. Defective in vitro growth of the hemopoietic progenitor cells in the acquired immunodeficiency syndrome. J Clin Invest. 1987;80:286-293.

65. Folks TM, Kessler SW, Orenstein JM, Justement JS, Jaffe ES, Fauci AS. Infection and replication of HIV 1 in purified progenitor cells of normal human bone marrow. Science. 1988;242:919-922.

\section{Publish your work in this journal}

Hepatic Medicine: Evidence and Research is an international, peerreviewed, open access journal covering all aspects of adult and pediatric hepatology in the clinic and laboratory including the following topics: Pathology, pathophysiology of hepatic disease; Investigation and treatment of hepatic disease; Pharmacology of drugs used for the treatment of hepatic disease. Issues of patient safety and quality of care will also be considered. The manuscript management system is completely online and includes a very quick and fair peer-review system, which is all easy to use. Visit http://www.dovepress.com/ testimonials.php to read real quotes from published authors.

Submit your manuscript here: http://www.dovepress.com/hepatic-medicine-evidence-and-research-journal 